\title{
Adjustment of Secondary School Students with Respect to Gender and Residence
}

\author{
Joymalya Paramanik, Birbal Saha ${ }^{1, *}$, Bhim Chandra Mondal ${ }^{2}$ \\ ${ }^{1}$ Department of Education, Sidho-Kanho-Birsha University, Purulia, WB, India \\ ${ }^{2}$ Sponsored Teachers' Training College, Purulia, WB, India \\ *Corresponding author: birbalsaha@gmail.com
}

Received November 12, 2014; Revised November 22, 2014; Accepted December 01, 2014

\begin{abstract}
The present work aims at studying the adjustment ability among secondary school students in relation to gender and residence. The sample consists of 471 class X students with 234 boys and 237 girls which were drawn randomly from different schools of Purulia districts, WB. The investigators have constructed and validate an Adjustment Inventory (AI) for school students to collect the necessary data. The study revealed that there is no significant difference between adjustments of students residing either at urban or rural area. But on the other hand the mean adjustment score of girls is higher than those from boys which indicate that the girls are better adjusted as compared to their boys counterpart.
\end{abstract}

Keywords: adjustment, gender, residence, ANOVA

Cite This Article: Joymalya Paramanik, Birbal Saha, and Bhim Chandra Mondal, "Adjustment of Secondary School Students with Respect to Gender and Residence.” American Journal of Educational Research, vol. 2, no. 12 (2014): 1138-1143. doi: 10.12691/education-2-12-2.

\section{Introduction}

Adjustment, in psychology, refers to the behavioral process by which humans and other animals maintain equilibrium among their various needs or between their needs and the obstacles of their environments. Human beings are able to adjust to the physical, social and psychological demands that arise from having inter dependability with other individual [1]. Adjustment, as a process describes and explains the ways and means of an individual's adaptation to his self and his environment without reference to the quality of such adjustment or its outcome in terms of success or failure. It is an organizational behavior in life situations at home, at school, at work in growing up and in ageing. It helps one to keep out basic impulses at tolerable levels, to believe in one's own abilities and to achieve desired goals. Thus, adjustment helps for self-initiated growth and development along intellectual, emotional, social, physical, and vocational dimensions. Adjustment refers to the psychological process through which people manage or cope with the demands and challenges of everyday life. It connotes conformity, it deals with the way an individual adapts to his environment and demand of life [2]. This includes how he relates to other (interpersonal) and how he deals with his responsibilities and inner feelings. Psychologically, adjustment helps the organism to cope with the demands and pressures of the outside world as well as the needs, desires and conflicts experiences from within [3].

In present, revolutionary changes are taking place in different fields and to cope up with such environment adjustment becomes necessary. To keep pace with the changing society, one has to make changes in our self or his environment. It the individual does not keep pace with the changing time, he is thrown back in the society. So the individual has to constantly make change in him to make the adjustment possible.

\section{The Review of Literature}

Singh (2006) examined the effects of socio, emotional and socio emotional climate of the school and sex on the adjustment of students along with their interactions effects. Boys were significantly better than girls in their health adjustment at different levels of socio-emotional climate of the school [4]. Raju and Rahamtulla (2007) intended to examine the adjustment capacity of school students and found that adjustment of school children is primarily dependent on the school variables like the class in which they are studying, the medium of instruction, and the type of management of the school [5]. Velmurugan and Balakrishnan (2011) examined the relationship between the social adjustment and self concept of the higher secondary school students with respect to gender and locality and they found that social adjustment is independent upon gender and locality. The correlation coefficient between social adjustment and self concept is found to be negligible [6]. Maureen et.al. (2011) made a study on school adjustment in relation to academic achievement and gender which revealed that there were no significant differences between girls and boys in school adjustment [7]. Kaur (2012) investigated the problems of adjustment in relation to achievement, sex and locality. He 
found that girls has more adjustment power than boys while locality does not influence adjustment power [8]. Basu (2012) aimed to investigate the adjustment abilities of secondary school students and found that there exist highly significant differences between the adjustment of secondary school students when compared on the basis of gender, type of family structure and medium of instruction in school [9]. Roy and Mitra (2012) examined the pattern of adjustment among early and late adolescent school students. The study revealed that early and late adolescents group differed significantly from each other in the home, health and social areas of adjustment. Girls showed better adjustment than boys [10]. Peerzada (2013) designed a study to compare the adjustment of science and social science higher secondary school teachers in different area like home adjustment, school adjustment, emotional adjustment etc. and showed that the social science teachers have more adjustment problems than science teachers [11].

Beside the above literature, it is also found that adjustment ability are strongly correlated with different variables like gender $[5,7,9,12,13]$, emotional intelligence [14,15,16,17,18], social intelligence [19], residence [20], achievement $[21,22,23]$, personality [24], steam of study [11], socio-economic status [25] etc.

Surveys of educational research reveals that no systematic attempt has yet been made to develop a tool for the assessment of adjustment ability of school students [26]. Child and adolescent adjustment ability have been largely neglected area in India. Looking into this perspective, current research work has been carried out in the area of high school students to identify the adjustment ability so that an adequate management could be formulate. That is why Investigators paid their attention on gender difference and residence in the adjustment ability of secondary school students.

\section{Objectives of the Study}

The present study was undertaken with the following objectives:

- To compare the differences in family adjustment, school adjustment, peer adjustment and overall adjustment with regard to gender and residence

- To study the interaction effect between independent variables i.e. between gender and residence with respect to family adjustment, school adjustment, peer adjustment and overall adjustment

\section{Hypotheses of the Study}

$\mathrm{H}_{1}$ : There is no significance difference in adjustment ability between urban and rural students with regard to family adjustment

$\mathrm{H}_{2}$ : There is no significance difference in adjustment ability between urban and rural students with regard to school adjustment

$\mathrm{H}_{3}$ : There is no significance difference in adjustment ability between urban and rural students with regard to peer adjustment

$\mathrm{H}_{4}$ : There is no significance difference in adjustment ability between urban and rural students with regard to overall adjustment
$\mathrm{H}_{5}$ : There is no significance difference in adjustment ability between boys and girls students with regard to family adjustment

$\mathrm{H}_{6}$ : There is no significance difference in adjustment ability between boys and girls students with regard to school adjustment

$\mathrm{H}_{7}$ : There is no significance difference in adjustment ability between boys and girls students with regard to peer adjustment

$\mathrm{H}_{8}$ : There is no significance difference in adjustment ability between boys and girls students with regard to overall adjustment

$\mathrm{H}_{9}$ : There is no significant interaction effect between gender and residence with regard to family adjustment

$\mathrm{H}_{10}$ : There is no significant interaction effect between gender and residence with regard to school adjustment

$\mathrm{H}_{11}$ : There is no significant interaction effect between gender and residence with regard to peer adjustment

$\mathrm{H}_{12}$ : There is no significant interaction effect between gender and residence with regard to overall adjustment

\section{Population}

All the Xth standard students of secondary level of Purulia district, West Bengal, are the population of this study.

\section{Sample}

Sample of 471 secondary school students were randomly selected from 8 secondary schools out of which 4 from urban area and 4 from rural area of Purulia district, West Bengal. The sample distribution is given in Table 1:

Table 1. Sample profile

\begin{tabular}{|c|c|c|c|}
\hline & Urban & Rural & Total \\
\hline Boys & 125 & 109 & 234 \\
\hline Girls & 89 & 148 & 237 \\
\hline Total & 214 & 257 & 471 \\
\hline
\end{tabular}

\section{Tool}

\subsection{Development of Adjustment Inventory}

Adjustment ability refers to a process whereby individuals interact with the environment to meet physical, psychological and social needs, and achieve a harmonious state [27]. This Inventory consisted with three factors, namely (i) Family adjustment: solving familial problems and the degree of happiness, (ii) School adjustment: academic achievement and individual progress, obeying school and class rules and (iii) Peer adjustment: admiring others, avoiding conflict, behaving appropriately, socializing with friends and willing to helping others, etc. [28]. This is three point Likert type scale consisting with 67 items by taking 23 items for family adjustment, 25 items for school adjustment and 19 items for peer adjustment. The scoring pattern of the scale is 2,1 and 0 for positive statement and reverse order was followed for negative statement having a score range 0 to 134 . 


\subsection{Reliability of the Tool}

Reliability refers to a measure of degree to which a research instrument yields consistent results or data after repeat trials [29]. Before the questionnaire was used in the actual study, it was piloted in population to determine its reliability and/or validity. This comprised a sample of thousand (1000) students from population under study. The split half reliability was found to be 0.74 . which is considered acceptable [30]. The Cronbach's coefficient alpha was computed in determining the internal consistency of the instruments. This method is considered more reliable compared to other methods since it is used in calculating the reliability of items that are not scored right versus wrong, as in some essay tests where more than one answer is possible [30].The Cronbach coefficient of Adjustment Inventory was found to be $0.81,0.73$ and 0.83 for the subscale of family, school and peer adjustment respectively. The Cronbach coefficient for the total scale was found to be 0.84 . So we may use it with confidence.

\subsection{Administration of Tool}

As indicated earlier, secondary school students were randomly sampled from different residential background of Purulia district, WB. It is always important to establish good rapport with the subjects, whether tested individually or in groups. 471 subjects comprising of 257 rural and 214 urban students were given the Adjustment Inventory (AI). All subjects were allowed to respond for 90 minutes to $120 \mathrm{~min}$ for responding. After the collection of data the responses of the participants were scored and after the final scoring the scores were analyzed in form of appropriate statistical tests.

\section{Analysis}

\subsection{Descriptive statistics}

Descriptive statistics help us to organize large amounts of data in a sensible way. Each descriptive statistic reduces lots of data into a simpler summary. Here we present our descriptive data (Table 2) in the form of Mean and Standard Deviation (SD) of boys, girls, rural and urban samples.

Table 2. Showing the Mean and SD of adjustment ability scores

\begin{tabular}{|c|c|c|c|c|c|c|c|c|c|}
\hline \multirow{2}{*}{ Pair of comparison } & \multirow{2}{*}{$\mathbf{N}$} & \multicolumn{2}{|c|}{ Family adjustment } & \multicolumn{2}{|c|}{ School adjustment } & \multicolumn{2}{|c|}{ Peer adjustment } & \multicolumn{2}{|c|}{ Overall adjustment } \\
\hline & & Mean & SD & Mean & SD & Mean & SD & Mean & SD \\
\hline Girls & 237 & 30.36 & 6.37 & 33.87 & 5.71 & 27.42 & 5.45 & 91.61 & 12.81 \\
\hline Boys & 234 & 29.20 & 6.49 & 32.10 & 6.29 & 26.29 & 6.03 & 87.72 & 13.73 \\
\hline Rural & 257 & 29.41 & 7.17 & 32.77 & 6.21 & 27.38 & 5.59 & 89.61 & 14.12 \\
\hline Urban & 214 & 30.22 & 5.89 & 33.25 & 5.89 & 26.43 & 5.91 & 89.76 & 12.54 \\
\hline
\end{tabular}

\subsection{Inferential Statistics}

Inferential statistics plays a pivotal role in hypothesis testing where it is used to determine if a null hypothesis can be rejected or retained. For the present study we have constructed a two way $(2 \times 2)$ factorial design for the analysis of different variables (Table 3). Table 4 represents the $\mathrm{t}-$ valuewhich is also used totest different null hypotheses.

Table 3. (a)Summary of two way ANOVA for family adjustment

\begin{tabular}{|l|c|c|c|c|}
\hline Source of variation & SS & df & MS & F ratio \\
\hline A (Gender) & 197.62 & 1 & 197.62 & $4.80^{*}$ \\
\hline B (Residence) & 118.53 & 1 & 118.53 & 2.87 \\
\hline A $\times$ B & 2.11 & 1 & 2.11 & 0.051 \\
\hline Within group & 19252.41 & 467 & 41.22 & \\
*= Significant at 0.05 level
\end{tabular}

Table 3. (b) Summary of two way ANOVA for school adjustment

\begin{tabular}{|l|c|c|c|c|}
\hline Source of variation & SS & df & MS & F ratio \\
\hline A (Gender) & 437.66 & 1 & 437.66 & $12.17^{* *}$ \\
\hline B (Residence) & 72.11 & 1 & 72.11 & 2.00 \\
\hline A $\times$ B & 58.44 & 1 & 58.44 & 1.62 \\
\hline Within group & 16786.99 & 467 & 35.95 & \\
\hline
\end{tabular}

Table 3. (c) Summary of two way ANOVA for peer adjustment

\begin{tabular}{|l|c|c|c|c|}
\hline Source of variation & SS & df & MS & F ratio \\
\hline A (Gender) & 109.39 & 1 & 109.39 & 3.34 \\
\hline B (Residence) & 91.88 & 1 & 91.88 & 2.82 \\
\hline A $\times$ B & 188.90 & 1 & 188.90 & $5.80 *$ \\
\hline Within group & 15200.62 & 467 & 32.55 & \\
\hline
\end{tabular}

$*=$ Significant at 0.05 level
Table 3. (d) Summary of two way ANOVA for overall adjustment

\begin{tabular}{|l|c|c|c|c|}
\hline Source of variation & SS & df & MS & F ratio \\
\hline A (Gender) & 1985.90 & 1 & 1985.90 & $11.28^{* *}$ \\
\hline B (Residence) & 79.63 & 1 & 79.63 & 0.45 \\
\hline A $\times$ B & 397.46 & 1 & 397.46 & 2.25 \\
\hline Within group & 82193.21 & 467 & 176.00 & \\
\hline
\end{tabular}

** = Significant at 0.01 level

Table 4. Determination of t-value

\begin{tabular}{|c|c|c|c|c|}
\hline Dimension & $\begin{array}{c}\text { Pair of } \\
\text { comparison }\end{array}$ & N & $\begin{array}{c}\text { Mean } \\
\text { difference }\end{array}$ & t-value \\
\hline \multirow{2}{*}{$\begin{array}{c}\text { Family } \\
\text { adjustment }\end{array}$} & Girls vs Boys & 471 & 1.17 & $1.97^{*}$ \\
\cline { 2 - 5 } & Rural vs Rural & 471 & 0.81 & 1.36 \\
\hline \multirow{2}{*}{$\begin{array}{c}\text { School } \\
\text { adjustment }\end{array}$} & Girls vs Boys & 471 & 1.78 & $3.21^{* *}$ \\
\cline { 2 - 5 } & Rural vs Rural & 471 & 0.48 & 0.85 \\
\hline \multirow{2}{*}{$\begin{array}{c}\text { Peer } \\
\text { adjustment }\end{array}$} & Girls vs Boys & 471 & 1.13 & $2.25^{* *}$ \\
\cline { 2 - 5 } & Rural vs Rural & 471 & 0.95 & 1.79 \\
\hline \multirow{2}{*}{$\begin{array}{c}\text { Overall } \\
\text { adjustment }\end{array}$} & Girls vs Boys & 471 & 3.89 & $3.18^{* *}$ \\
\cline { 2 - 5 } & Rural vs Rural & 471 & 0.16 & 0.13 \\
\hline
\end{tabular}

$*=$ Significant at 0.05 level and $* *=$ significant at 0.01 level

\section{Results and Discussion}

\subsection{Testing of Hypothesis $\mathrm{H}_{1}$}

It is observed from Table 2 that mean adjustment ability test scores for urban and rural student with regard to family adjustment are 30.22 and 29.41 respectively. ANOVA results as obtained from Table 3(a) showed F 
value as 2.87 which is not significant at 0.01 level. Moreover, from Table 4, it is noted that t-critical ratio between urban and rural is found to be 1.36 which is not significant at 0.01 level.In the light of the above finding, $\mathrm{H}_{1}$ is accepted.This results supported by the findings of Kaur[8] and Parmar [31].

\subsection{Testing of Hypothesis $\mathbf{H}_{2}$}

Mean adjustment ability test scores for urban and rural student with regard to school adjustment are 33.25 and 32.77 respectively. Table $3(\mathrm{~b})$ showed $F$ value for residence is 2.00 which is not significant at 0.01 level. Moreover, from Table 4, it is noted that t-critical ratio between urban and rural is found to be 0.85 which is also not significant at 0.01 level. In the light of the above finding, $\mathrm{H}_{2}$ is accepted. This result supported by the findings of Kaur[8].

\subsection{Testing of Hypothesis $\mathrm{H}_{3}$}

Mean adjustment ability test scores for urban and rural student with regard to peer adjustment are 26.43 and 27.38 respectively. ANOVA result (Table 3.c) indicating F value as 2.82 which is not significant at 0.01 level. Moreover, from Table 4, it is noted that t-critical ratio between urban and rural is found to be 1.79 which is also not significant at 0.01 level. In the light of the above finding, $\mathrm{H}_{3}$ is accepted. This result supported by the findings of Velmirugan and Balakrishnan [6], Kaur [8], Parmar [32]. On peer adjustment dimension, the rural and urban students do not differ significantly. In urban and rural family environment, socialization of children is almost similar. Both types of environment are helpful in learning social adjustment.

\subsection{Testing of Hypothesis $\mathrm{H}_{\mathbf{4}}$}

Mean adjustment ability test scores for urban and rural student with regard to overall adjustment are 89.76 and 89.61 respectively. ANOVA result (Table 3.d) indicating $\mathrm{F}$ value as 2.25 which is not significant at 0.01 level. Moreover, from Table 4, it is noted that t-critical ratio between urban and rural is found to be 0.13 which is also not significant at 0.01 level. In the light of the above finding, $\mathrm{H}_{4}$ is accepted. Thus it can safely be said that residence does not influence the adjustment level of the students. This result supported by the findings of Kaur[8], Rajeswari and Eljo [33], Parmar [32] but not matched with Ambedkar [34]. In urban and rural areas parents take equal care to teach adjustment in different areas of life. Therefore, the overall adjustment is equal in rural and urban students.

\subsection{Testing of Hypothesis $\mathbf{H}_{5}$}

ANOVA result presented in Table 3(a) shows significant difference at 0.05 level $(F=4.80)$ of mean adjustment ability test scores of the student belongs to different sex i.e. boys and girls with respect to family adjustment. From Table 2, it is clear that the mean of obtained scores for girls (30.36) is higher than boys (29.20) having a difference of 1.16. Further, ' $t$ ' value (Table 4) was found to be 1.97 which is also significant at 0.05 levels. In the light of the above finding, $\mathrm{H}_{5}$ is rejected.
This result corroborates with the findings of Kaur [8] but did not match with the finding of Singh et.al [35].

\subsection{Testing of Hypothesis $\mathbf{H}_{6}$}

ANOVA result $(\mathrm{F}=12.17)$ presented in Table 3(b) shows significant difference of mean adjustment ability test scores at 0.01 level of the student belongs to different sex i.e. boys and girls with respect to school adjustment. From Table 2, it is clear that the mean of obtained scores for girls (33.87) is higher than boys (32.10) having a difference of 1.77. Further, 't' value (Table 4) was found to be 3.21 which is significant at 0.01 levels. In the light of the above finding, $\mathrm{H}_{6}$ is rejected. This result corroborates with Kaur [8] but did not match with the finding of Singh et.al [35].

\subsection{Testing of Hypothesis $\mathbf{H}_{7}$}

ANOVA result $(\mathrm{F}=3.34)$ presented in Table 3(c) shows significant difference of mean adjustment ability test scores at 0.05 level of the student belongs to different sex i.e. boys and girls with respect to peer adjustment. From Table 2, it is clear that the mean of obtained scores for girls (27.42) is higher than boys (26.29) having a difference of 1.13. Further, 't' value (Table 4) was found to be 3.21 which is significant at 0.01 levels. In the light of the above finding, $\mathrm{H}_{7}$ is rejected. The present results are in harmony with those of Jatikumar and Muthumanickam [36] and Mansinghbhai [21].

\subsection{Testing of Hypothesis $\mathbf{H}_{8}$}

Mean adjustment ability test scores for girls and boys with regard to overall adjustment are found to be 91.61 and 87.72 respectively. ANOVA result (Table 3.d) indicating $\mathrm{F}$ value as 11.28 which is significant at 0.01 level. Moreover, from Table 4, it is noted that t-critical ratio between urban and rural is found to be 3.18 which is also significant at 0.01 level. In the light of the above finding, $\mathrm{H}_{8}$ is rejected. The result indicates that girls students has higher adjustment ability than boys counterpart. The findings of this study are in harmony with those of Rajuand Rahamtulla [5], Maureen [7], Kaur [8], Basu [9], Patel [12], Chauhan [13], Mansinhbhai and Patel [21], Ambedkar [34] who revealed that female has higher adjustment ability than that of their male counterpart but did not match with the result of Singh et.al [35], Yellaiah [20] and Gehlawat [37]. This might be possible due to the societal norms whichare also different for boys and girls, Boys are more free and capable to get what they want which is not possible for girls. Moreover child rearing practices towards girls in our society also make difference in adjustment ability between boys and girls [38].

\subsection{Testing of Hypotheses $H_{9}, H_{10}, H_{11}$ and $\mathrm{H}_{12}$}

The F- value for the interaction of variables viz. gender and residence $(\mathrm{A} \times \mathrm{B})$ with respect to family, school, peer and overall adjustment are found to be 0.05, 1.62, 5.80 and 2.25 respectively (Table 3 ) which are not significant at 0.01 level but for peer adjustment it is significant at 
0.05 level. So, $\mathrm{H}_{9}, \mathrm{H}_{10}$ and $\mathrm{H}_{12}$ are accepted while $\mathrm{H}_{11}$ is rejected at 0.05 level.

\section{Conclusion}

The findings of the present study indicate that there exist significant differences between the secondary school students on the basis of gender but no difference was found locale where they reside. Since these differences are found to be highly significant for gender in all the domains of adjustment i.e. family, peer and social adjustment, there seems to be an urgent need to improve the situation. This calls for priority based action on the part of academicians, policy makers, families and all the concerned stakeholders to devise measures to facilitate better adjustment skills among the secondary school students.

The secondary school students are at a very crucial stage of their lives wherein they are still in the process of exploring their place and role in society. It is at this stage of their lives that they are most in need of their adjustment abilities. All the concerned stakeholders ought to chalk out a plan of action whereby the adjustment skills are honed and differences arising due to various demographic factors are minimized. In order to fulfill their demands following activities to be performed:

1. Family has to create such an environment so that they can express their opinion without hesitation. Also parent has to take care of both boys and girls equally.

2. School has to organize NCC/NSS activities that would develop desirable social qualities considerate and cooperation which in turn help them to adjust well.

3. Students should be given an opportunity to express their own ideas and discuss their problems with school authorities. It develops self confidence and mental satisfaction among the students.

4. There is badly need a guidance and counseling cell for each school which serve to assist students in coping and adjusting to school life.

\section{References}

[1] Shaffer, L.F. (1961). Article in Boring, LongfiledandWelb (Eds.), Foundations of Psychology, New York: John Wiley.

[2] Ogoemeka, O.H. (2012). A Study of The Emotional Intelligence and Life Adjustment of Senior Secondary School Students in Nigeria, The 2012 Orlando International Academic Conference, Orlando, Florida, USA 59.

[3] Dickens, W.T. (2006). Cognitive Ability, The New Dictionary of Economics, Steve Durlauf(ed).

[4] Singh, H. (2006). Effect of Socio Emotional Climate of the School on the Adjustment of Students.Psycho lingua, 36(2), 133- 143.

[5] Raju, M.V.R. and Rahamtulla, T.K. (2007). Adjustment Problems among School Students, Journal of the Indian Academy of Applied Psychology, 33(1), 73-79.

[6] Velmurugan, K. and Balakrishnan, V., A (2011). Study on Self Concept of Higher Secondary Students in relation to Social Adjustment, International Journal of Current Research, 3(11), 340-343.

[7] Maureen, W. John, A. and Ayere, A.M. (2011). The Relationship among School Adjustment, Gender and Academic Achievement amongst Secondary School Students in Kisumu District Kenya, Journal of Emerging Trends in Educational Research and Policy Studies 2(6), 493-497.
[8] Kaur, S. (2012), A Study of Adjustment of High School students in Relation to Their Achievement, Sex and Locality, International Journal of Research in Education, Methodology Council For Innovative Research, 1(2), 18-21.

[9] Basu, S. (2012), Adjustment of Secondary School Students, Scholarly Research Journal for Interdisciplinary Studies, 1(3), 430-38.

[10] Roy, B. and Mitra, S. (2012). Pattern of Adjustment among Early and Late Adolescent School Students, International Indexed \& Referred Research Journal, Vol. IV, Issue: 42.

[11] Peerzada, N. (2013). Adjustment of Science and Social Science Higher Secondary School Teachers - A Comparative Study. Academ Arena, 5(2), 34-38.

[12] Patel, H.T (2013). A Study of Emotional Intelligence and Adjustment of 9th Standard Students, International Journal for Research in Education, Vol. 2, Issue: 6, June 2013.

[13] Chauhan, V. (2013). A study on adjustment of higher secondary school students ofDurg district,IOSR Journal of Research \& Method in Education, 1(1) 50-52.

[14] Chen, F.S., Lin, Y.M. \&Tu, C.A. (2006). A Study of the Emotional Intelligence and Life Adjustment of Senior High School Students, World Transactions on Engineering and Technology Education Vol.5, No.3, 473-476.

[15] Safavi M, Mousavi LS, Lotfi R (2008). Correlation between Emotional Intelligence and Socio-emotional Adjustment in Preuniversity Girl Students in Tehran. Pajoohandeh Journal, 1(5): 255-261.

[16] Thilagavathy, T. (2013).Adjustment and Emotional Intelligence of High School Teachers in Tiruvarur district, International Journal of Teacher Educational Research, Vol.2 No.5.

[17] Punia, S. and Sangwan, S. (2011). Emotional Intelligence and Social Adaptation of School Children, Journal of Psychology, 2(2): 83-87.

[18] Ishak, N., Jdaitawi, M. T. and Ibrahim, Y. S. (2011). Moderating Effect of Gender and Age on the Relationship between Emotional Intelligence with Social and Academic Adjustment among First Year University Students, International Journal of Psychological Studies, Vol. 3, No. 1.

[19] Nagra, V. (2014).Social Intelligence and Adjustment of Secondary School Students, PERIPEX-Indian Journal of Research, 3(4), 8687.

[20] Yellaiah (2012). A Study of Adjustment on Academic Achievement on Higher School Students, International Journal of Social Sciences and Interdisciplinary Research, 1(5),84-94.

[21] Mansingbhai, S.T and Patel, Y.H. (2014). Adjustment and Academic Achievement of Higher Secondary School Students, Journal of Information, Knowledge and Research in Humanities and Social Sciences, 3(1), 128-130.

[22] Gupta, M and Gupta, R. (2011).Adjustment and Scholastic Achievement ofBoys \& Girls, VSRD International Journal of Business \& Management Research, 1 (1), 29-33.

[23] Gaur, A. (2013). A Comparative Study of Adjustment Problems of High and Low Achivers in Higher Secondary School of Gwalior City (M.P), Asian Journal of Multidisciplinary Studies, 1(4), 6771.

[24] Devi, N (2011). A Study of Adjustment of Students in relation to Personality and Achievement Motivation, Bhartiyam International Journal of Education and Research, 1(1),

[25] Mistry, M (2014). Adjustment of the school student of the high school students with reference to birthorder and SES, Voice of Research, Vol. 3 Issue 1, 10-11.

[26] Buch, M.B. (1991). Fourth Survey of Research in Education, NCERT, New Delhi

[27] Tallent, N. (1978). Psychology of Adjustment : Understanding Ourselves and Others, Van Nostrand Reinhold (International)

[28] Derlega, V.J and Janda, L.H. (1986). Personal Adjustment; The Psychology of Everyday Life (3rd edn.). Reading: Addison Wesley.

[29] Mugenda, O.M..andMugenda, A. B. (1999). Research Methods. Quantitative and Qualitative Approaches. Nairobi: African Center for Technology Studies (ACTS) Press.

[30] Fraenkel, J.R., \&Wallen, N. E. (4th Ed.). (2000). How to Design and Evaluate Research in Education. San Francisco State University.The McGraw-Hill Companies.

[31] Parmar, G.B. (2012). A Study of adjustment of the Secondary School Students, International Indexed \& Referred Research Journal, IV (41), 21-22.

[32] Parmar, R.N. (2014). A study of certain areas of adjustment of higher secondary school's students in relation to habitat, 
International Journal For Technological Research In Engineering 1(6), 403-406.

[33] Rajeswari, S. and Eljo, J. O. J. G. (2013). A Study on Emotional Adjustment of Adolescent School Students, International Journal of Humanities Social Sciences, 2(2), 49-56.

[34] Ambedkar, V. (2013). Social maturity and adjustment of higher secondary students, Indian Stream Research Journal, 3(1).

[35] Singh, T.K., Tripathi, S and Mahato, J. (2014). Health and Adjustment of High School Students, The International Journal of Indian Psychology, 1(4), 9-18.
[36] Jaikumar, S. and Muthumanickam, R. (2010), Social Adjustment of Higher Secondary School Students, International Journal of Recent Scientific Research, 1, 036-038.

[37] Gehlawat, M. (2011). A Study of Adjustment among High School Students in relation to their Gender, Inernational Reffered Research Journal, III (33).

[38] Jain, P. and Jandu, K. (1998).A Comparative Study of School Adjustment of Adolescent Girls and Boys of Employed and Nonemployed Mothers in age group 14-18 years. Journal of Educational Research and Extension, 35(2): 14-21. 